\title{
LVI. On the calculus of variations
}

\section{John Walsh Esq.}

To cite this article: John Walsh Esq. (1824) LVI. On the calculus of variations, Philosophical Magazine Series 1, 64:319, 330-332, DOI: 10.1080/14786442408644613

To link to this article: http://dx.doi.org/10.1080/14786442408644613

$$
\text { 曲 Published online: } 27 \text { Jul } 2009 .
$$

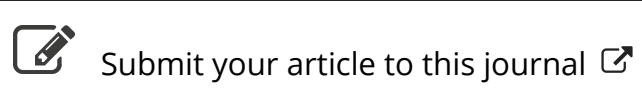

\footnotetext{
Џ Article views: 4
}

Q View related articles $\asymp$ 


\section{[ 390 ]}

LVI. On the Calculus of Variations. By JoHn W Wush, Esq.

To the Editors of the Philosophical Magazine and Journal.

Gentlemen,

PERHaps you will be so good as to insert the following paper in the next Number of your very valuable Journal, if not too much preoccupied.

I have the honour to be, gentlemen, Your much obliged servant,

Sept. 30, 1824.

John Walsh.

Let $A B$ be any straight line bisected in $C$, and let $E$ be any other point in $A B$, then

$(\mathrm{AB}-\mathrm{AC} \mp \mathrm{CE})(\mathrm{AC} \pm \mathrm{CE})=\mathrm{AB} \times \mathrm{AC}-\mathrm{AC}^{2} \pm$

$$
(\mathrm{AB}-2 \mathrm{AC}) \mathrm{CE}-\mathrm{CE}^{2} \text {. }
$$

or, as $A B$ is equal to $2 A C$,

$$
(\mathrm{AB}-\mathrm{AC} \mp \mathrm{CE})(\mathrm{AC} \pm \mathrm{CE})=\mathrm{AB} \times \mathrm{AC}-\mathrm{AC}^{2}-\overline{\mathrm{CE}}^{2} \text {. }
$$

The preceding is the demonstration of prop. v. book 2, of the Elements of Euclid. We see by it, as $\mathrm{CE}^{2}$ is negative, whether $\mathrm{CE}$ itself is positive or negative, that the maximum rectangle under the two segments of any given straight line takes place when the line is bisected. The condition of maximum requires, therefore, that the coefficient of $\mathrm{CE}$ the arbitrary magnitude added to and taken from $\mathrm{AC}$, should be nothing, and that $\overline{C E^{2}}$ should be negative.

Clothing the preceding equation in the notation of the differential calculus, there is given, in the case of maximum,

$$
a d x-2 x d x=0
$$

in which $a=\mathrm{AB}, x=\mathrm{AC}^{\prime}, d x=\mathrm{CE}, d x$, being considered indefinitely small. Clothing this last in the notation of the calculus of variations, there is given, in the case of maximum,

$$
\begin{gathered}
\int \delta(a d x-2 x d x)=0 . \\
\int\{a d \delta x-2 x d \delta x-2 \delta x d x\}=0 .
\end{gathered}
$$

Integrating by parts, the integral is,

$$
a \delta x-2 x \delta x+\int\{2 \delta x d x-2 \delta x d x\}
$$

It is seen, that the terms remaining under the integral sign destroy one another. We are left, therefore, by the calculus of variations, at the point at which we set out, and we have 
not still for the determination of the maximum, but the original equation,

$$
a d x-2 x d x=a \delta x-2 x \delta x=0 .
$$

I shall take now what is called the differential equation of the curve of quickest descent. Finding the variation, and integrating, then

$$
\frac{\delta s}{u}+\int\left\{\frac{\delta s d u}{u^{2}}-\frac{d s \delta u}{u^{2}}\right\}=0 .
$$

The terms remaining under the integral sign destroying one another, there is still for the determination of the minimum, only, the original equation, $\frac{\delta s}{u}=\frac{d s}{u}=0$.

Thus, it is first of all demonstrated, by the fifth proposition of the second book of Euclid, that the calculus of variations is no calculus at all. Its nonentity is self-evident; for it consists in ascending from the second term of the development of a binomial to the third, and then redescending again, leaving us at the point at which we set out; doing and then undoing to no purpose. The Institute of France was too hasty in the reports which it gave of every paper, in fact, which I addressed to it.

“M. Walsh croit que cette demonstration est la seule rigoureuse qui ait été donnée jusqu'à présent pour le cas dont il s'agit. Cependant il suffit d'avoir lu les ouvrages d'Euler ou des géomètres qui ont écrit apres lui sur cet objet, pour être bien convaincu que la formule du binome est depuis longtemps êtablie en toute rigueur."-Extrait du procès=verbal de la Séance du Lundi, 24: Décembre 1821.

" L'auteur s'est proposé d'établir un théorème qu'on peut exprimer comme il suit: Chaque terme du développement de la $n^{\text {me }}$ puissance du binome surpasse en valeur numérique la somme des termes suivants.-Ce théorème suppose évidemment que le second terme du binome à une valeur numérique inférieure à celle du premier."-Lundi, 24 Février 1823.

With respect to the development of a binomial when the exponent is a negative whole number, let

$$
(x+h)^{-n}=\frac{1}{(x+h)^{n}}=\frac{1}{x^{n}+z} .
$$

developing the right hand member by division, and arranging according to $h, \mathrm{I}$ get,

$$
(x+h)^{-n}=x^{-n}-n x^{-n-1} h+\frac{n(n+1)}{1.2} x^{-n-2} h^{2}-8 c .
$$

The preceding is the demonstration to which the first of the T t 2 preceding 
preceding extracts refers. The Institute of France calls it a pretended demonstration. Then all our numerical divisions are only pretended. I have given the only general demonstration of the formula of the binomial that has as yet appeared. It was read by the Royal Society of London, June 6, 1821. Had I sent it to the Institute of France, it would have been called pretended, and rejected. The second extract refers to the dinomial theorem. The report asserts, that the theorem evidently supposes, the second term of the binomial to be less than the first. The paper of mine in the Philosophical Magazine for last June, demonstrates that the Institute is in error in coming to such a conclusion; for the theorem is demonstrated in that paper when both the terms of the binomial are equal to each other. The dinomial theorem is a general law of all series. It has banished more errors from algebra than has the system of Copernicus banished from physical astronomy. The following is its enunciation in the most general sense.

In every series, the sign of any term after the first, is the sign of that term combined with all those that follow it.

This grand theorem has banished fluxions, differentials, and the calculus of variations, and has extended the domain of algebra without limit.

The following is from the last report which the Academy of Sciences has given with respect to the binomial calculus, that $I$ have received:

"Les commissaires ont été d'avis que les memoires de M. Walsh n'apprenoient rien de nouveau, ils croient ne devoir attacher aucune importance au nom que l'auteur voudra donner à son calcul, et se dispenseront de fixer plus long-temps sur ces objets l'attention de l'Académie."

"Lundi, 16 Juin, 1823." " (Signé) Poisson, Cauchy, Rapporteur."

The influence which the infinitesimal calculus has so long exercised in geometry and analysis, has not permitted the Royal Academy of Sciences of Paris to perceive clearly its way through the binomial calculus. The preceding demonstration of the fifth proposition of the second book of Euclid, first, demonstrates the absurdity of the logic of the infinitesimal calculus; secondly, it developes the general theory of maxima and minima; and, thirdly, it demonstrates the nonentity of the calculus of variations,

Cork, Sept. 30, 1824.

LVII. On 